\title{
HUBUNGAN ANTARA PEMBERIAN ASI EKSKLUSIF DENGAN STATUS GIZI BALITA DI WILAYAH KERJA PUSKESMAS WARUNGGUNUNG TAHUN 2018
}

\author{
Daini Zulmi \\ Akbid La Tansa Mashiro \\ Korespondensi: dainizulmi@gmail.com
}

\begin{abstract}
Malnutrition in infancy is a very serious problem because if toddlers have poor or even poor nutritional status, there will be various delays and irreversible damage. Based on PSG of the primary health care Warunggunung in 2016-2017 is higher than several categories: poor nutrition (2.93\%) to (2.38\%), malnutrition (10.09) to (11.09\%). The purpose of this study was to determine the relationship between the history of exclusive breastfeeding and the nutritional status of child under fifth age 12-59 months in at the primary health care Warunggunung 2018. The type of research used is analytic, with a case control design. The population in this study were 379 toddlers, sample were 60 toddlers with a rasio of 1:2. The results of the univariate analysis that under-five children who experienced malnutrition and poor nutrition were used as a sample of $20(33.33 \%)$ toddlers and those who experienced good nutrition were used as a control group of 40 (66.67\%) toddlers, almost half (38.33\%) toddlers are not given exclusive breastfeeding. The results of the bivariate analysis showed a significant relationship between the history of exclusive breastfeeding and the nutritional status of under-five children ( $p$-value $=0.00)$ OR $=8.04$. Paramedices are expected to further improve services in providing counseling, information and education about exclusive breastfeeding, convincing every mother to be able to breastfeed exclusively from the time of pregnancy to breastfeeding to give exclusive breastfeeding and continue for 2 years which is the initial stage of toddlers having good nutritional status.
\end{abstract}

Keywords: exclusive breastfeeding, nutritional status

\begin{abstract}
ABSTRAK
Gizi pada masa balita merupakan hal yang perlu diperhatikan lebih serius karena jika balita memiliki status gizi yang kurang atau bahkan buruk maka akan terjadi berbagai keterlambatan dan kerusakan yang tidak dapat dipulihkan (irreversibel). Berdasarkan Pemantauan Status Gizi Puskesmas Warunggunung tahun 2016-2017 mengalami peningkatan dibeberapa kategori: gizi buruk $(2,93 \%)$ menjadi $(2,38 \%)$, gizi kurang $(10,09)$ menjadi $(11,09 \%)$. Tujuan penelitian ini untuk mengetahui hubungan antara pemberian ASI eksklusif dengan gizi balita 12-59 bulan di wilayah kerja Puskesmas Warunggunung tahun 2018. Jenis penelitian yang digunakan adalah analitik, dengan pendekatan case control. Populasi pada penelitian ini adalah 379 balita jumlah sample 60 balita dengan rasio 1:2. Hasil analisis univariat bahwa balita yang mengalami gizi kurang dan buruk dijadikan sebagai sampel kasus sebanyak $20(33,33 \%)$ balita dan yang mengalami gizi baik dijadikan kelompok kontrol sebanyak $40(66,67 \%)$ balita, hampir setengahnya $(38,33 \%)$ balita tidak diberikan ASI eksklusif. Hasil analisis bivariat terdapat hubungan yang bermana antara riwayat pemberian ASI eksklusif dengan status gizi balita ( $\mathrm{p}$ value $=0,00)$ OR $=8,04$. Tenaga kesehatan diharapkan agar lebih meningkatkan pelayanan dalam memberikan KIE (konseling, informasi dan edukasi) tentang ASI eksklusif, meyakinkan setiap ibu untuk bisa menyusui secara eksklusif sejak masa kehamilan hingga menyusui untuk
\end{abstract}


memberikan ASI eksklusif dan diteruskan sampai 2 tahun yang menjadi tahap awal balita memiliki status gizi yang baik.

Kata Kunci: ASI Ekslusif, Status Gizi Balita

\section{PENDAHULUAN}

Status gizi pada masa balita perlu mendapatkan perhatian yang serius dari para orang tua, pada usia 2-5 tahun (Golden Age) zat gizi hanya digunakan untuk pertumbuhan dan perkembangan yang sangat cepat, akan tetapi jika kekurangan gizi dapat menyebabkan kerusakan yang irreversibel (tidak dapat dipulihkan). Kekurangan gizi yang lebih fatal akan berdampak pada perkembangan otak. Fase perkembangan otak pesat pada usia 30 minggu-18 bulan. Status gizi balita dapat diketahui dengan cara mencocokkan umur anak dengan berat badan standar dengan menggunakan pedoman WHO (World Health Organization)-NCHS (National Center for Health Statistics). (Maryam, 2016).

Menurut Blössner dan Mercedes de Onis (2005) dalam Andriani, dkk (2015) hasil dari delapan penelitian tentang epidemiologi malnutrisi menunjukkan bahwa malnutrisi merupakan masalah yang sangat serius karena berkaitan dengan peningkatan risiko morbiditas dan mortalitas. Faktanya, sebagian besar kematian terkait gizi buruk dikaitkan dengan status gizi kurang dikarena populasi status gizi kurang lebih banyak dibandingkan dengan status gizi buruk. Penelitian ini juga menegaskan walaupun malnutrisi bukan penyebab langsung kematian tapi memiliki efek multiplikasi pada kematian.

Secara klasik kata gizi hanya dihubungan dengan kesehatan tubuh, yaitu untuk menyediakan energi, membangun, dan memelihara jaringan tubuh, serta mengatur proses-proses kehidupan dalam tubuh. Tetapi sekarang kata gizi mempunyai pengertian lebih luas; disamping untuk kesehatan, gizi dikaitkan dengan potensi ekonomi seseorang, karena gizi berkaitan dengan perkembangan otak, kemampuan belajar, dan produktivitas kerja. Oleh karena itu, di Indonesia yang sekarang sedang membangun, faktor gizi di samping faktorfaktor lainnya dianggap penting untuk memacu pembangunan, khususnya yang berkaitan dengan sumber daya manusia berkualitas (Almatsier, 2011).

Masa balita merupakan periode terpenting dalam pertumbuhan dan 
perkembangan anak. Karena pada saat ini pertumbuhan dasar akan mempengaruhi perkembangan anak selanjutnya. Pada masa balita kemampuan yang bisa dikembangkan diantaranya berbahasa, kreativitas, kesadaran sosial, emosional dan intelegensia yang berjalan cepat dan merupakan landasan perkembangan berikutnya. Perkembangan moral dan dasar-dasar kepribadian juga dibentuk pada masa balita. Sehingga setiap kelainan sekecil apapun apabila tidak terdeteksi apalagi tidak tertangani dengan baik akan mengurangi kualitas sumber daya manusia kelak (Adriani, 2014).

Menurut Depkes RI (2010), munculnya masalah gizi pada anak balita dipengaruhi oleh banyak faktor yang saling berkaitan. Secara langsung dipengaruhi oleh beberapa hal, yaitu anak tidak cukup mendapat makanan bergizi seimbang pada usia balita, anak tidak mendapatkan asuhan gizi yang memadai dan anak menderita penyakit infeksi. Kemiskinan juga merupakan salah satu penyebab munculnya kasus gizi buruk terkait ketersediaan dan konsumsi pangan keluarga (Handayani, 2017). Munculnya masalah gizi pada balita dimulai dari lingkup keluarga yang kurang memadai.

Hak dasar anak salah satunya adalah pemenuhan gizi. Upaya untuk meningkatkan kesehatan anak menurut kesepakatan internasional seperti Konvensi Hak Anak (Komisi Hak Azasi Anak PBB, 1989, Pasal 24) adalah memberikan makanan yang terbaik bagi anak usia di bawah 2 tahun. Untuk mencapai target tersebut, Strategi Nasional Peningkatan Pemberian ASI dan MP-ASI merekomendasikan pemberian makanan yang baik dan tepat bagi bayi dan anak 0-24 bulan, yaitu mulai menyusu dalam 1 jam setelah melahirkan, menyusu secara eksklusif sampai usia 6 bulan, memberikan Makanan Pendamping ASI (MP-ASI) mulai usia 6 bulan, dan meneruskan menyusu sampai usia 2 tahun atau lebih. (Irianto, K. 2014).

Menurut Roesli (2005) dalam Atiqa (2016) pemberian ASI Eksklusif memberi dampak baik bagi tubuh bayi yaitu sebagai makanan tunggal untuk memenuhi semua kebutuhannya, meningkatkan daya tahan tubuh bayi, sebagai anti alergi, meningkatkan kecerdasan dan meningkatkan jalinan kasih sayang antara ibu dan bayi. Hal ini sejalan dengan riset yang dilakukan WHO pada tahun 2005 menyebutkan bahwa 42 persen penyebab kematian balita di dunia terbesar adalah malnutrisi (58\%), sedangkan riset WHO pada tahun 2000 menyebutkan bahwa kurang dari $15 \%$ bayi di seluruh dunia diberikan ASI Eksklusif selama 4 bulan dan seringkali memberikan makanan pendamping ASI tidak sesuai dan tidak 
aman. Pada pertemuan tingkat tinggi di markas PBB pada September 2015, Pemerintah di setiap negara anggota PBBbaik negara kaya, menengah, maupun miskin, baik negara maju maupun berkembang - memiliki tanggung jawab mengimplementasikan SDGs untuk mencapai SDGs yang berlaku selama 15 tahun ke depan mulai 2016 hingga 2030. Salah satu tujuan dari 17 tujuan SDGs adalah Kesehatan (Health)- Menjamin hidup yang sehat dan meningkatkan kesehatan / kesejahteraan bagi semua pada semua usia (ICPH, 2018).

Persentase cakupan balita 0-59 bulan menurut status gizi dengan indeks BB/U tahun 2016-2017 Indonesia mengalami kenaikan di dua kategori yaitu gizi buruk dari $3,40 \%$ menjadi $3,80 \%$ dan gizi lebih dari $1,47 \%$ menjadi $1,80 \%$. Sedangkan untuk kategori gizi kurang mengalami penurunan dari $14,43 \%$ menjadi $14 \%$ dan gizi baik dari $80,70 \%$ menjadi $80,40 \%$. (BKKBN, 2017).

Provinsi Banten tahun 2016-2017 mencatat angka cakupan gizi balita 0-59 bulan dengan indeks $\mathrm{BB} / \mathrm{U}$ mengalami kenaikan di gizi kurang dari 13,89\% menjadi $15,70 \%$ dan gizi lebih dari1,83\% menjadi 2,20\%. Sedangkan untuk kategori gizi buruk mengalami penurunan dari 4,24\% menjadi $4 \%$ dan gizi baik dari $80,05 \%$ menjadi 78,10\% .(BKKBN, 2017). Hasil studi pendahuluan di Puskesmas Warunggunung yang berada di Kabupaten Lebak berdasarkan data Pemantaun Status Gizi (PSG) tahun 2015 dengan populasi 1772 balita 12-59 bulan, frekuensi gizi buruk $(1,02 \%)$, gizi kurang $(6,66 \%)$, gizi baik (90,12\%). Data tahun 2016 dengan populasi 2.085 balita 12-59 bulan, frekuensi gizi buruk yaitu (2,93\%), gizi kurang $(10,09 \%)$, gizi baik $(83,56)$. Sedangkan pada tahun 2017 dengan populasi 2.353 balita 1259 bulan mengalami kenaikan dibeberapa kategori diantaranya, frekuensi balita dengan gizi buruk yaitu (2,38\%), gizi kurang $(11,09 \%)$, gizi baik $(85,17 \%)$. Pada salah satu desa wilayah kerja Puskesmas Warunggunung tahun 2018 dengan populasi 379 balita 12-59 bulan menjadi desa tertinggi yang mencatat angka status gizi buruk yaitu $(4,49 \%)$. Sedangkan untuk gizi kurang yaitu $(7,39 \%)$, gizi baik $(87,33 \%)$. Berdasarkan latarbelakang diatas peneliti tertarik untuk melakukan penelitian adakah hubungan antara ASI Ekslusif terhadap Gizi Balita di wilayah kerja Puskesmas Warunggunung Kabupaten Lebak tahun 2018.

\section{METODE}

Jenis penelitian analitik (kuantitatif) dengan rancangan case control. Adapun Independent variabel yaitu Pemberian ASI Eksklusif dan Dependent variabel yaitu 
Gizi Balita 12-59 Bulan. Populasi dalam penelitian ini adalah semua balita di salah satu desa yang banyak mengalami masalah gizi di wilayah kerja Puskesmas Warunggunung tahun 2018 sebanyak 379 balita. teknik pengambilan sampel dengan Unmatched Case Control, maka untuk menentukan besar sampel dalam penelitian ini menggunakan epiinfo.exe.versi 7. Sampel yang digunakan peneliti $1: 2$. Maka sampel minimal dalam kelompok kasus adalah 10 balita yang status gizi kurang dan sampel minimal kelompok kontrol adalah 20 balita yang status gizi baik. Jadi jumlah sampel minimal adalah 30 balita. Pada penelitian ini peneliti menggunakan sampel kasus 20 balita dan sampel kontrol 40 balita. Jadi jumlah semua sampel yang diambil adalah 60 balita.

\section{HASIL}

\section{Analisis Univariat}

\section{Tabel 1 \\ Distribusi Frekuensi Balita Berdasarkan Status Gizi Di Wilayah Puskesmas Warunggunung Tahun 2018.}

\begin{tabular}{clc}
\hline Status Gizi & Frekuensi & Persentase \\
\hline $\begin{array}{c}\text { Kurang+ } \\
\text { Buruk }\end{array}$ & 20 & 33,33 \\
\hline Baik & 40 & 66,67 \\
\hline Total & 60 & 100 \\
\hline
\end{tabular}

Berdasarkan tabel diatas menunjukkan bahwa balita yang mengalami gizi kurang dan buruk dijadikan sebagai sampel kasus sebanyak $20(33,33 \%)$ balita dan yang mengalami gizi baik dijadikan sampel kontrol sebanyak $40 \quad(66,67 \%)$ balita dengan menggunakan rasio 1:2.

Tabel 2
Distribusi Frekuensi Balita Berdasarkan
Pemberian ASI Eksklusif di Wilayah
Kerja Puskesmas Warunggunung Tahun 2018

\begin{tabular}{ccc}
\hline ASI Eksklusif & Frekuensi & Persentase \\
\hline Tidak & 23 & 38,33 \\
\hline Ya & 37 & 61,67 \\
\hline Total & 60 & 100 \\
\hline
\end{tabular}

Berdasarkan tabel diatas menunjukkan bahwa hampir setengahnya $38,33 \%$ balita tidak diberikan ASI eksklusif.

\section{Analisi Bivariat}

Tabel 3

Hubungan Pemberian ASI Eksklusif Dengan Status Gizi Balita Wilayah Kerja Puskesmas Warunggunung Tahun 2018

\begin{tabular}{|c|c|c|c|c|c|c|c|c|}
\hline \multirow{3}{*}{$\begin{array}{c}\text { ASI } \\
\text { Eksklusif }\end{array}$} & \multicolumn{5}{|c|}{ Status Gizi } & \multirow[b]{2}{*}{ Total } & \multirow{3}{*}{$\begin{array}{c}\text { P- } \\
\text { Valu } \\
\text { e }\end{array}$} & \multirow{3}{*}{ OR } \\
\hline & \multicolumn{2}{|c|}{$\begin{array}{l}\begin{array}{c}\text { Kurang } \\
\text { +buruk }\end{array} \\
\end{array}$} & \multicolumn{2}{|c|}{ Baik } & & & & \\
\hline & $\boldsymbol{F}$ & $\%$ & $F$ & $\%$ & $F$ & $\%$ & & \\
\hline Tidak & 14 & 70 & 9 & 22,5 & 23 & 38,33 & & \\
\hline Ya & 6 & 30 & 31 & 87,5 & 37 & 61,67 & 0,00 & 8.04 \\
\hline$F(\%)$ & 20 & 100 & 40 & 100 & 60 & 100 & & \\
\hline
\end{tabular}

Berdasarkan tabel diatas menunjukan bahwa kelompok balita yang tidak diberikan ASI eksklusif lebih banyak yang mengalami gizi kurang dan buruk sebesar $70 \%$ dibandingkan dengan balita 
dengan gizi baik sebesar 22,5\%. Hasil uji statistik diperoleh nilai $\mathrm{p}=0,00(\mathrm{p}<0,05)$, artinya terdapat hubungan yang bermakna antara riwayat pemberian ASI Eksklusif dengan status gizi pada balita 12-59 bulan di desa Jagabaya wilayah kerja Puskesmas Warunggunung tahun 2018. Bila dilihat dari nilai Odds Ratio (OR) sebesar 8.04, maka balita yang tidak diberikan ASI eksklusif berisiko 8 kali lebih besar mengalami status gizi kurang dan buruk.

\section{PEMBAHASAN}

Berdasarkan hasil uji statistik peneliti diperoleh nilai $\mathrm{p}=0,00(\mathrm{p}<0,05)$, artinya terdapat hubungan yang bermakna antara pemberian ASI Eksklusif dengan status gizi pada balita di wilayah kerja Puskesmas Warunggunung tahun 2018. Bila dilihat dari nilai Odds Ratio (OR) sebesar 8.04, maka balita yang tidak diberikan ASI eksklusif berisiko 8 kali lebih besar mengalami status gizi kurang dan buruk.

Sesuai dengan hasil penelitian Kartiningrum (2015), menyimpulkan bahwa riwayat ASI Ekslusif merupakan faktor risiko terjadinya gizi kurang pada balita karena terdapat pengaruh yang signifikan, dimana balita yang tidak mendapatkan ASI eksklusif memiliki risiko mengalami kejadian kurang baik.
ASI mengandung gizi yang cukup lengkap, ASI juga mengandung antibodi atau zat kekebalan yang akan melindungi balita terhadap infeksi. Hal ini yang menyebabkan balita yang diberi ASI, tidak rentan terhadap penyakit dan dapat berperan langsung terhadap status gizi balita. Selain itu, ASI disesuaikan dengan sistem pencernaan karena mengandung enzim pencernaan sehingga zat gizi cepat terserap.

Sejalan dengan penelitian Kartiningrum, hasil penelitian yang dilakukan Normayanti dan Susanti (2013) dengan p-value 0,003 dan nilai OR 6,667, menunjukkan bahwa terdapat hubungan yang berarti antara riwayat pemberian ASI Eksklusif dengan status gizi balita karena sebelum usia 6 (enam) bulan, sistem pencernaan bayi belum dapat mencerna makanan atau minuman selain ASI sehingga jika dipaksakan maka berpotensi menderita infeksi terutama pada sistem pencernaan. Balita yang mengalami infeksi sangat mudah mengalami penurunan status gizi.

Jika dilihat dari dua penelitian di atas maka dapat disimpulkan bahwa balita yang mendapatkan ASI eksklusif memiliki zat kekebalan yang lebih baik terutama pada sistem pencernaan, dimana pada masa bayi ASI merupakan makanan yang paling mudah dicerna dan mengandung 
zat gizi yang sempurna. Hal ini sesuai dengan teori Acandra dalam penelitian Atika (2014) bahwa ASI merupakan makanan yang paling cocok pada bayi saat usia 0-6 bulan karena mempunyai nilai gizi yang paling tinggi dibandingkan makanan yang dibuat oleh manusia ataupun susu yang berasal dari hewan, seperti susu sapi, susu kerbau atau susu kambing. Sedangkan menurut Prasetyono dalam penelitian Atika (2014) ASI mengandung zat gizi berkualitas tinggi berguna untuk pertumbuhan dan perkembangan dan mengandung komposisi sesuai kebutuhan yang diperlukan. Maka bayi yang diberi ASI eksklusif cenderung memiliki status gizi yang baik karena disebabkan gizi yang cukup yang diperoleh dari ASI. Dan ditambah dengan makanan pendamping ASI yang bergizi membuat pertumbuhan dan perkembangan menjadi stabil hingga usia balita.

Sejalan dengan teori di atas, menurut Soekirman dalam penelitian Dewi Novitasari (2012) Selain ASI mengandung gizi yang cukup lengkap, ASI juga mengandung antibodi atau zat kekebalan yang akan melindungi balita terhadap infeksi. Hal ini yang menyebabkan balita yang diberi ASI, tidak rentan terhadap penyakit dan dapat berperan langsung terhadap status gizi balita. Berdasarkan analisis peneliti bahwa pemberian ASI eksklusif sangat berpengaruh dengan status gizi balita dan sesuai dengan yang terjadi di lapangan. Tubuh balita yang pernah diberikan ASI secara eksklusif saat berumur 0-6 bulan memiliki pertahanan yang lebih baik dibandingkan balita yang tidak diberikan ASI eksklusif terhadap berbagai macam infeksi yang turut andil dalam mempengaruhi status gizi balita. Seperti teori yang telah dipaparkan di atas bahwa ASI merupakan makanan yang sempurna untuk bayi 0-6 bulan dimana sistem tubuh yang masih dalam fase penyesuaian dan bekerja secara lambat sehingga ASI menjadi menu yang pasti memenuhi semua kriteria tubuh saat itu untuk mempersiapkan kebutuhan yang sejalan dengan bertambahnya usia.

Meskipun di lapangan terdapat balita yang tidak diberikan ASI eksklusif dan memiliki gizi yang baik, hal tersebut dikarenakan balita mendapatkan makanan tambahan setelah 6 bulan (MP-ASI) yang lebih baik dibandingkan balita lain namun tetap saja keuntungan dari ASI eksklusif tidak dimiliki oleh balita tersebut seperti zat kekebalan yang baik terhadap infeksi. Begitu pun terdapat juga bayi yang diberikan ASI eksklusif namun memiliki status gizi yang kurang, hal tersebut 
terjadi karena makanan pendamping yang diberikan tidak sesuai dengan kebutuhan balita. Saat usia $>6$ bulan ASI tidak dapat memenuhi kebutuhan seperti sebelumnya karena proses pertumbuhan dan perkembangan yang pesat dan sistem tubuh yang sudah mulai bekerja semestinya, maka disarankan untuk diberikan makanan pendamping yang bernutrisi agar semua berjalan secara optimal. Jadi dalam penelitian ini penelit berasumsi bahwa ASI eksklusif merupakan sebuah langkah awal untuk balita memiliki gizi yang baik, dimulai dari terbentuknya zat-zat kekebalan dalam tubuh balita yang sudah terbentuk saat bayi dan sistem tubuh yang sudah terlatih sesuai dengan tahapannya membuat balita memiliki status gizi yang baik dan membuat pertumbuhan dan perkembangannya optimal.

\section{SIMPULAN}

Berdasarkan paparan hasil penelitian maka dapat disimpulkan bahwa terdapat hubungan pemberian ASI Eksklusif dengan Status Gizi Balita. Hampir setengahnya $(38,33 \%)$ balita tidak diberikan ASI eksklusif. Kelompok balita yang tidak diberikan ASI eksklusif lebih banyak memiliki status gizi kurang dan buruk. Balita yang tidak diberikan ASI eksklusif berisiko 8 kali lebih besar untuk mengalam status gizi kurang dan buruk.

\section{DAFTAR RUJUKAN}

A, Dewi Novitasari. 2012. Faktor-Faktor Risiko Kejadian Gizi Buruk Pada Balita Yang Dirawat di RSUP dr. Kariadi Semarang. Laporan Akhir Hasil Penelitian Karya Tulis Ilmiah Fakultas Kedokteran Universitas Diponegoro.

Andriani, dkk. 2015. Hubungan Pemberian Asi Eksklusif Dengan Kejadian Status Gizi Kurang Pada Balita Umur 1 - 5 Tahun. Jurnal Wiyata, Vol. 2 No. 1 S1 Kesehatan Masyarakat IIK Bhakti Wiyata: Kediri

Almatsier. 2011. Prinsip Dasar Ilmu Gizi. Gramedia: Jakarta.

Atika. N. 2014. Perbedaan Pemberian ASI Eksklusif dan Susu Formula terhadap Status Gizi Bayi Usia 7-12 Bulan. Karya Tulis Ilmiah Akademi Kebidanan Ngudi Waluy: Ungaran.

Atiqa, UD. 2016. Perbedaan Pertumbuhan dan Perkembangan Bayi Usia 6 Bulan yang Diberikan ASI Eksklusif dan Non Eksklusif. Makasar. Skripsi. Fakultas Kedokteran Universitas Hasanuddin.

BKKBN. 2017. Survey Demografi dan Kesehatan Indonesia: Jakarta http://sdki.bkkbn.go.id/?lang=id (Diakses pada tanggal 01 Oktober 2018)

Handayani. 2017. Faktor-Faktor Yang Berhubungan Dengan Status Gizi Pada Anak Balita. Journal Endurance 2(2) Juni 2017 (217-224)

ICPH. 2018. Sustainable

Development Goals: Jakarta http://theicph.com/id_ID/icph/sustainab le-development-goals/ (Diakses pada tanggal 30 September 2018)

Irianto, K. 2014. Ilmu Kesehatan Anak. Alfabet: Bandung.

Kartiningrum. 2015. Faktor Risiko Kejadian Gizi Kurang Pada Balita Di Desa Gayaman Kecamatan Mojoanyar Mojokerto. Hospital Majapahit Vol 7 No. 2

Maryam. S. 2012. Gizi dalam Kesehatan Reproduksi. Salemba Medika: 2016 